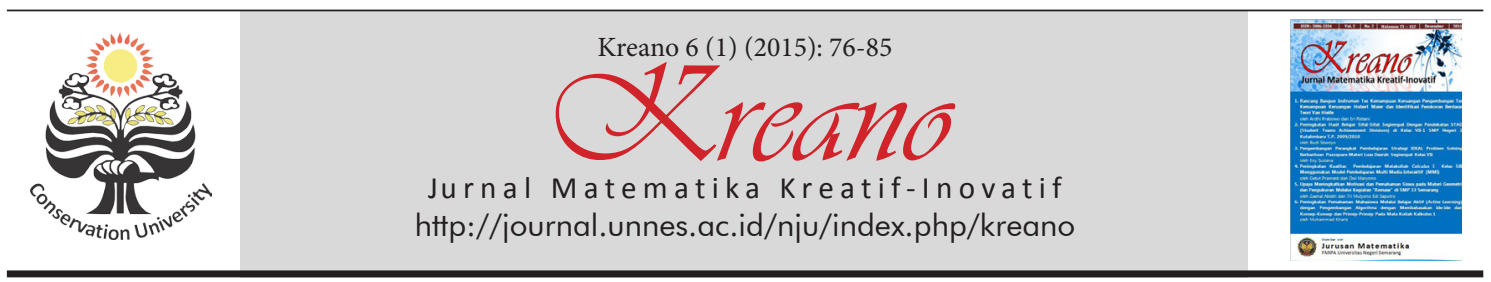

\title{
Desain Pembelajaran Materi Luas Permukaan Prisma Menggunakan Pendekatan PMRI bagi Siswa Kelas VIII
}

\author{
Trisnawati, D. ${ }^{1}$, Putri, R.I.I, dan Santoso, B. \\ 'Pendidikan Matematika Pascasarjana Universitas Sriwijaya Palembang \\ Email: di_wiwit@yahoo.com 1
}

DOI: http://dx.doi.org/10.15294/kreano.v6i1.4504

Received : August 2015; Accepted: September 2015; Published: September 2015

\begin{abstract}
Abstrak
Penelitian ini bertujuan menghasilkan lintasan belajar untuk membantu siswa dalam pembelajaran luas permukaan prisma menggunakan kemasan produk di kelas VIII SMP. Penelitian ini berdasarkan PMRI yang dikaitkan dengan pembelajaran Kurikulum 2006/KTSP. Metode yang digunakan dalam penelitian ini adalah design research type validation study yang bertujuan untuk membuktikan teori-teori pembelajaran. Penelitian ini dilaksanakan di SMP Negeri 24 Palembang dengan melibatkan siswa kelas VIII yang berjumlah 31 siswa. Aktivitas-aktivitas pembelajaran yang dilakukan siswa meliputi: 1) memahami bentuk dan sifat prisma, 2) menemukan dan memahami konsep luas permukaan prisma, dan 3) menyelesaikan permasalahan dalam kehidupan sehari-hari yang berhubungan dengan luas permukaan prisma. Hasil dari penelitian ini menunjukkan bahwa melalui serangkaian aktivitas yang telah dilakukan membantu siswa dalam pembelajaran luas permukaan prisma.
\end{abstract}

\begin{abstract}
This research aimed to produce learning trajectory in learning surface area of prism using product packaging in class VIII. This study was based PMRI associated with learning curriculum 2006 / KTSP. The method used was design research of type validation study that aimed to prove the theories of learning. The research was conducted on 31 students of class VIII SMPN 24 Palembang. Students learning activities that were conducted including: (1) comprehending the shape and the characteristic of prism, (2) finding and comprehending the concept surface area of prism, and (3) solving the problems in daily life related to the surface area of prism. The results of this study indicate that a series of activities can help students in learning surface area of prism.
\end{abstract}

Keywords: surface area of prism; product packaging; PMRI approach; design research

\section{PENDAHULUAN}

Luas merupakan konsep penting dalam geometri yang mendasari berbagai aspek matematika (French, 2004). Konsep luas adalah memahami bagaimana sebuah unit tertentu dapat menutupi permukaan bidang datar secara iterasi dan menyeluruh (Cavanagh, 2008). Namun menurut French (2004) luas menciptakan kesulitan konseptual bagi siswa. Siswa masih bingung memahami luas permukaan bangun ruang karena siswa sulit untuk memvisualisasikan bidang tiga dimensi dan merepresentasikannya ke dalam bentuk dua dimensinya.

Secara khusus menurut CPRE (2007) dalam menemukan luas permukaan dapat menggunakan model konkret dan jaringjaring (model dua dimensi). Selanjutnya menurut Kershaw (2013) untuk menentukan luas permukaan harus dapat menghitung luas dari masing-masing sisi, kemudian menjumlahkan luas-luas tersebut dan satu jalan untuk melakukan hal tersebut adalah dengan menggunakan sebuah jaring-jaring. Berdasarkan penjelasan tersebut, pembelajaran konsep luas permukaan seharusnya dapat menggunakan benda konkret yang bertujuan agar siswa mampu mempresentasikan bentuk dua dimensi dari bidang ruang. Bentuk dua dimensi yang didapat merupakan jaring-jaring dari 
bidang ruang tersebut dan selanjutnya akan ditentukan jumlah luasnya.

Luas permukaan bangun ruang dipelajari di kelas VIII Sekolah Menengah Pertama (SMP) dengan kompetensi menentukan luas permukaan dan volume kubus, balok, prisma dan limas (Kemendikbud 2013). Hal ini menunjukkan bahwa siswa diharapkan mampu menentukan dan memahami luas permukaan bangun ruang. Namun kenyataannya siswa masih lemah dalam melakukan perhitungan luas khususnya yang berkaitan dengan materi luas permukaan prisma. Hal ini ditunjukkan dari hasil penelitian Yan, Bistari \& hamdani (2013) yang menganalisis kesalahan jawaban siswa, diketahui bahwa kesalahan siswa yang dominan muncul dalam menyelesaikan soal tentang luas permukaan prisma adalah kesalahan konsep. Lemahnya pemahaman siswa mengenai luas permukaan juga ditemukan dari hasil penelitian Bonotto (2003) yang menemukan bahwa pemahaman siswa pada materi luas permukaan hanya sebatas tingkat numerik bukan pada makna menentukan luas. Mengingat masih lemahnya kemampuan siswa dalam konsep luas permukaan khususnya permukaan prisma, maka konsep luas permukaan perlu dipelajari dan dipahami oleh seswa secara benar.

Dari permasalahan di atas, maka perlu mendesain pembelajaran yang lebih bermakna pada materi luas permukaan prisma. Peneliti akan melakukan suatu penelitian design research yang mengembangkan serangkaian aktivitas menggunakan pendekatan Pendidikan Matematika Realistik Indonesia (PMRI) yang lebih menekankan pada kebermaknaan konsep. Pendekatan PMRI telah berlangsung sejak 2001 (Zulkardi, 2009) dan telah banyak digunakan dalam upaya memperbaiki minat siswa, sikap dan hasil belajar. Pembelajaran matematika dengan pendekatan PMRI bertitik tolak dari konteks atau situasi "real" yang pernah dialami oleh siswa yang merupakan jembatan untuk menghubungkan siswa dari tahap real ke arah formal matematik. Fungsi konteks dalam RME yang juga dikenal dengan Pendidikan Matematika Realistik Indonesia (PMRI) dimana konteks sebagai titik awal bagi siswa dalam mengembangkan pengertian matematika dan sekaligus menggunakan konteks tersebut sebagai sumber aplikasi matematika (Zulkardi dan Putri, 2006). Pada penelitian ini konteks yang digunakan adalah kemasan produk yang berbentuk prisma. Kemasan produk ini digunakan sebagai konteks awal pembelajaran matematika dalam menentukan konsep luas permukaan prisma. Kontek kemasan produk ini memberikan situasi riil sebagai titik awal untuk membantu proses pembelajaran. Pemanfaatan benda-benda nyata ini selain sebagai awal pengenalan konsep bangun ruang juga lebih mendekatkan siswa dengan dunia nyata dalam belajar geometri (Sumardyono, 2012). Pembelajaran yang dilaksanakan dengan memanfaatkan media pembelajaran berupa benda-benda yang ada di sekitar siswa seperti halnya barang bekas dapat meningkatkan keaktifan, motivasi dan hasil belajar siswa pada materi sifat-sifat bangun ruang (Yayuk:2010)

Berdasarkan latar belakang yang dikemukakan di atas, penelitian ini bertujuan untuk mengetahui peran penggunaan kemasan produk dapat membantu siswa memahami konsep luas permukaan prisma di kelas VIII SMP.

\section{METODE}

Penelitian ini menggunakan metode penelitian desain (design research) yang mendesain materi luas permukaan prisma dengan pendekatan PMRI untuk kelas VIII SMP menggunakan kemasan produk sebagai awal pembelajaran. Metode design research yang digunakan type validation studies yang bertujuan untuk membuktikan teori-teori pembelajaran (Nieveen, McKenney, Akker, 2006). Ini merupakan cara yang tepat untuk menjawab pertanyaan peneliti dan mencapai tujuan dari penelitian. Penelitian ini terdiri dari tiga tahap yang dapat dilakukan secara berulangulang sampai ditemukannya teori baru yang merupakan hasil revisi dari teori pembelajaran yang dicobakan. Tahapan yang dilalui terdiri dari sederetan aktivitas siswa yakni dugaan-dugaan strategi dan pemikiran siswa yang dapat berubah dan berkembang selama proses pembelajaran yang menunjukkan bahwa terdapat siklus proses yang berulang dari eksperimen pemikiran (thought experiment) menuju eksperimen pembelajaran (intruction 


\section{experiment).}

Gravemeijer dan Cobb (2006) menyatakan bahwa ada 3 tahap dalam pelaksanaan design research. Tahap pertama: preparing for the Experiment/Preliminary Design (Persiapan untuk Penelitian/Desain Pendahuluan). Pada tahap ini dilakukan kajian literatur mengenai materi pembelajaran yaitu luas permukaan prisma, pendekatan PMRI, kurikulum 2006, dan design research sebagai dasar perumusan dugaan strategi awal siswa dalam pembelajaran luas permukaan prisma. Selanjutnya akan didesain hypothetical learning trajectory (HLT). Berupa serangkaian aktivitas pembelajaran luas permukaan prisma menggunakan pendekatan PMRI memuat dugaan-dugaan yang terdiri dari tujuan pembelajaran, aktivitas pembelajaran dan perangkat yang dapat membantu proses pembelajaran. Dugaan tersebut dijadikan pedoman untuk mengantisipasi strategi dan berpikir siswa yang muncul dan dapat berkembang pada aktivitas pembelajaran. Dugaan ini bersifat dinamis sehingga dapat disesuaikan dengan reaksi siswa dalam belajar dan direvisi selama teaching experiment.

Tahap kedua: the design experiment (desain percobaan) yang terdiri preliminary teaching experiment (pilot experiment) dan teaching experiment. Pilot experiment dilakukan untuk mengujicobakan HLT yang telah dirancang pada siswa dalam kelompok kecil guna mengumpulkan data dalam menyesuaikan dan merevisi HLT awal untuk digunakan pada tahap teaching experiment nantinya. Siswa yang dilibatkan dalam Pilot experiment sebanyak 6 siswa dimana peneliti akan berperan sebagai guru. Pada teaching experiment, HLT yang telah diujicobakan pada tahap pilot experiment dan telah direvisi kemudian diujicobakan kembali pada kelas yang merupakan subjek penelitian. Guru matematika bertindak sebagai guru model (pengajar) dan peneliti melakukan observasi terhadap aktivitas pembelajaran dan komunikasi matematika siswa.

Tahap ketiga: retrospective analysis. data yang diperoleh dari tahap teaching experiment dianalisis dan hasil analisis ini digunakan untuk merencanakan kegiatan dan mengembangkan rancangan kegiatan pada pembelajaran berikutnya. Tujuan dari retros- pective analysis secara umum adalah untuk mengembangkan local instructional theory (LIT). Pada tahap ini, HLT dibandingkan dengan pembelajaran siswa yang sebenarnya, hasilnya digunakan untuk menjawab rumusan masalah. Teknik pengumpulan data yang digunakan pada saat penelitian seperti rekaman video, observasi, wawancara, dokumentasi, dan catatan lapangan yang dikumpulkan dan dianalisis untuk memperbaiki HLT yang telah didesain. Data yang diperoleh dianalisis secara retrospektif bersama HLT yang menjadi acuannya. Untuk analisis data didiskusikan oleh peneliti yang bekerja sama dengan pembimbing dan guru model untuk meningkatkan reliabilitas dan validitas pada penelitian ini berupa observasi, wawancara, dan dokumentasi dilakukan secara kualitatif.

\section{HASIL DAN PEMBAHASAN}

\section{Hasil}

Pembelajaran ini didesain untuk melihat peran kemasan produk melalui aktivitas yang didesain telah membantu siswa untuk pembelajaran luas permukaan prisma. Artikel ini fokus pada saat teaching experiment yang diujikan pada 31 siswa. Pembelajaran ini bertujuan untuk memahami konsep luas permukaan prisma melalui aktivitas-aktivitas yang dilakukan untuk menjadikan siswa tidak mengalami kesulitan dalam memahami materi karena menurut Soedjadi (2007) penyebab kesulitan siswa belajar matematika bisa bersumber dari dalam diri siswa maupun dari luar siswa, misalnya cara penyajian materi pembelajaran atau suasana pembelajaran dilaksanakan. Berdasarkan desain lintasan belajar yang telah dirancang dan dilakukan oleh peneliti, lintasan belajar dalam pembelajaran luas permukaan prisma meliputi memahami bentuk dan sifat prisma, menemukan dan memahami konsep luas permukaan prisma, dan menyelesaikan permasalahan dalam kehidupan sehari-hari. Pendekatan PMRI, serangkaian urutan kegiatan dan beberapa pembelajaran luas permukaan prisma menjadi acuan utama dalam setiap aktivitas pembelajaran yang telah dilaksanakan pada setiap siklus.

Pembelajaran yang dilaksanakan menggunakan kemasan produk sebagai 
starting point untuk mengawali materi tentang luas permukaan prisma. Aktivitas yang dilakukan menunjukkan bahwa siswa mengeksplorasi pengetahuan awal melalui kegiatan menggunakan kemasan produk untuk menentukan bentuk dan sifat prisma, menggunakan kemasan produk untuk menemukan dan memahami konsep luas permukaan prisma dengan cara memotong bagian rusuk kemasan sehingga didapat bagian-bagian berupa bangun datar sederhana pembentuk prisma, dan menyelesaikan masalah dalam kehidupan sehari-hari yang berhubungan dengan luas permukaan prisma.

Pada saat proses pembelajaran, siswa sangat antusias dalam mengerjakan tiap soal pada lembar aktivitas dan menggunakan kemasan produk yang diberikan. Pendesainan aktivitas ini mengacu pada lima karakteristik PMRI yakni pembelajaran harus diawali dengan penggunaan konteks yang bertujuan untuk meningkatkan motivasi dan ketertarikan siswa dalam belajar (de Lange dalam wijaya, 2012). Sebelum dan sesudah melakukan serangkaian aktivitas pembelajaran, siswa diberikan tes awal (pretest) dan tes akhir (postest). Dari kedua tes ini, peneliti memperoleh informasi bahwa hasil pekerjaan siswa menunjukkan ada perbedaan antara tes awal (pretest) dan tes akhir (postest) dalam memahami luas permukaan prisma. Melalui aktivitas yang telah didesain mampu membuat pengetahuan siswa bertambah dalam menyelesaikan masalah tentang luas permukaan prisma. Berdasarkan hasil analisis retrospektif, ketika tes awal (pretest) masih banyak siswa yang belum mampu menjawab sebagian besar dari soal-soal yang diberikan. Tetapi pada tes akhir (postest) siswa telah mampu menyelesaikan berbagai permasalahan mengenai luas permukaan prisma. Tidak hanya itu, di akhir aktivitas beberapa siswa juga telah mampu mengungkapkan penalarannya dengan baik. Dengan demikian, dapat disimpulkan bahwa pengetahuan dan kemampuan berpikir siswa mengenai masalah luas permukaan prisma telah meningkat.

\section{Pembahasan}

Aktivitas pertama didesain untuk mengingatkan kembali kemampuan memahami bentuk dan sifat-sifat prisma karena pada dasarnya siswa sudah mampu memahami bentuk prisma namun belum dapat memahami sifat prisma. Pada saat kerja kelompok, siswa mulai saling berdiskusi dan bertanya dengan teman. Peneliti sebagai observer melihat pekerjaan setiap kelompok dan memberikan arahan terhadap pertanyaan yang mereka berikan.

Guru : "dariberbagaikemasanini, tentukan mana yang termasuk prisma dan mana yang bukan prisma!"

Fernando: "yang ini prisma dan yang ini bukan Buk (sambil menunjukkan kemasan produk yang diberikan)".

Guru: $\quad$ "kenapa yang ini termasuk prisma (sambil menunjuk kemasan produk)"

Achmad : "karena alas dan atapnya sama besar Buk"

Guru : "nah sekarang, kenapa kemasan ini bukan prisma?"

Achmad : "karena yang ini balok Buk dan yang satu ini sisi alas dan atapnya tidak sama"

Guru : "Tolong perhatian bentuk alas dan atap balok ini! Mana yang merupakan alas? berbentuk apa alasnya?

Achmad : "yang ini buk, bentuknya persegi panjang"

Guru : "terus atapnya berbentuk apa?"

Achmad : "persegi panjang juga buk"

Guru : "tadi kata kalian prisma itu cirri-cirinya apa?"

Achmad : "Bentuk alas dan atapnya sama"

Guru : "jadi balok termasuk prisma atau bukan?"

Fernando: "termasuk buk"

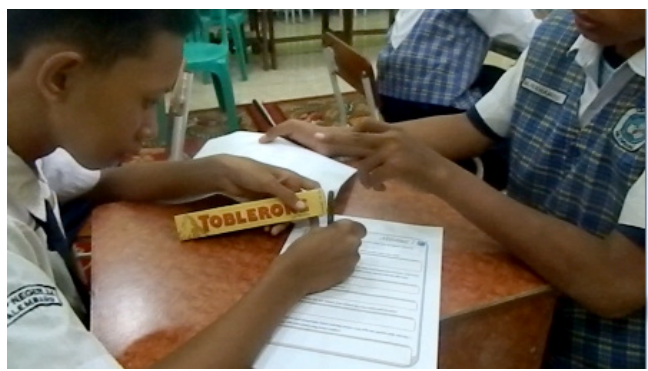

Gambar 1. Siswa bekerjasama mengamati kemasan produk

Transkrip 1 dan gambar 1 menunjukkan aktivitas siswa menggunakan kemasan produk untuk menentukan unsur dan sifat prisma.

Aktivitas kedua bertujuan menemukan dan memahami konsep luas permukaan prisma menggunakan kemasan produk yaitu 
dengan memotong bagian rusuk kemasan sehingga didapat bagian berupa bangun datar sederhana pembentuk kemasan/prisma. Siswa masih tetap berdiskusi kelompok seperti pada aktivitas sebelumnya. Untuk soal pertama siswa sedikit kebingungan ketika mensketsa bangun datar hasil potongan kemasan yang merupakan bagian permukaan kemasan. Berikut transkrip percakapan siswa dan guru ketika bingung mensketsa gambar.

\begin{tabular}{|c|c|}
\hline Annisa & $\begin{array}{l}\text { :"buk maksudnya disketsa ini } \\
\text { bagaimanayabuk?" }\end{array}$ \\
\hline Guru & $\begin{array}{l}\text { :"maksudnya, bagian permukaan } \\
\text { kemasan yang kalian potong tadi } \\
\text { digambar pada tabel di LAS" }\end{array}$ \\
\hline Edo & $\begin{array}{l}\text { : "besar buk hasil potongan tadi, ng- } \\
\text { gak muat kalau digambar di tabel!" }\end{array}$ \\
\hline Guru & $\begin{array}{l}\text { :"menggambar potongannya bukan } \\
\text { dengan ukuran yang sama, ukuran- } \\
\text { nya disesuaikan dengan tabel tapi } \\
\text { bentuk bangun datarnya harus sama } \\
\text { dengan hasil potongan" }\end{array}$ \\
\hline Annisa & $\begin{array}{l}\text { :"seperti ini ya buk?" (siswa sambil } \\
\text { menunjukkan hasil gambar poton- } \\
\text { gan pada tabel) }\end{array}$ \\
\hline Guru & $\begin{array}{l}\text { :"nah begitu baru benar, lanjutkar } \\
\text { mengerjakan LASnya!" }\end{array}$ \\
\hline & $u k^{\prime \prime}$ \\
\hline
\end{tabular}

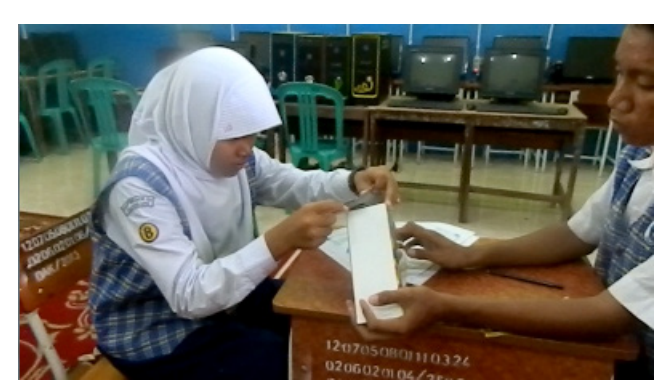

Gambar 2 Siswa bekerjasama memotong kemasan produk dan menggambar hasil potongan pada LAS

Pada transkrip 2 dan gambar 2 menunjukkan kegiatan siswa menggunakan memotong kemasan produk guna untuk mengambil bagian terluar atau yang menutupi kemasan produk berupa bangun datar sederhana. Kemudian hasil potongan itu nantinya digambar dengan ukuran yang disesuaikan pada tabel di LAS tetapi tetap tidak mengubah bentuk bangun datar itu dan menuliskan nama bangun datar sederhana yang didapat dari hasil potongan tadi. Pada soal nomor 2 dan nomor 3 kegiatan 3, siswa tidak mengalami kesulitan. Tetapi ketika akan mengerjakan soal nomor 4, siswa mengalami kesulitan dalam menjawabnya. Berikut percakapan antara guru dan siswa ketika membahas soal nomor 4 kegiatan 3.

Achmad :"buk yang nomor 4 ini bagaimanaya buk? Nggak ngerti maksudnya"

Guru :"begini nak, hasil potongan yang kalian dapat tadi jika kita satukan kembali jadi apa bentuknya?"

Achmad :"jadi seperti semula sebelum dipotong buk, tadi bentuknyanya prisma segitiga sama sisi"

Guru : "Nah coba sekarang pikirkan, hasil potongan tadi jadi apanya prisma?"

Achmad :"bangun pembentuk prisma atau permukaan prisma"

Guru : "jadi jika kita ingin mencari luas permukaan prisma, harus diapakanlah bangun-bangun tadi?"

Achmad :"ditambahkan bukan buk?"

Guru :"nah iya betul. Jadi untuk mencari luas prisma sisi-sisinya harus di?"

Achmad :"tambahkan"

Luas bangun $1+L$. bangun $2+L$. bangun $3+L$. bangun $4+$

l. bagen 5 : luas permukaan prisma

Gambar 3 Contoh jawaban siswa untuk soal nomor 4 kegiatan 3 pada LAS 1

Berdasarkan transkrip 3 dan gambar 3 , pada kegiatan 4 siswa tidak mengalami kesulitan yang berarti. Siswa sudah mulai terarah dalam mengilustrasikan cara mencari luas permukaan prisma sesuai dengan permasalahan yang diberikan. Pada kolom terakhir di LAS, siswa membuat kesimpulan megenai aktivitas-aktivitas yang telah mereka lakukan. Kesimpulan yang dibuat siswa pada aktivitas ini berkaitan dengan kegiatan sebelumnya yaitu membuat ilustrasi bahwa untuk menemukan luas permukaan prisma siswa dapat menjumlahkan semua sisi-sisi pada prisma seperti halnya terlihat pada gambar 4 . 


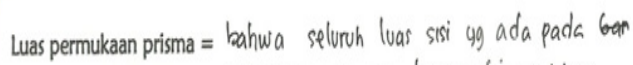

Gambar 4 Contoh jawaban siswa dalam menarik kesimpulan pada $\mathrm{LAS}_{1}$

Secara keseluruhan aktivitas ini membantu siswa menemukan konsep untuk mencari luas permuakaan prisma. Dengan demikian, dapat disimpulkan bahwa aktivitas 2 ini dapat digunakan pada siklus 2 (teaching experiment) dengan terdapat revisi pada LAS yaitu mengganti kalimat pada nomor 1 kegiatan 3 yang tadinya tertulis "beri warna yang sama untuk bangun ruang dengan bentuk dan ukuran yang sama" diganti menjadi "berilah nomor pada bangun datar yang kalian gambar". Berdasarkan aktivitas ini, dapat dilihat sejauh mana pemahaman siswa mengenai konsep untuk mencari luas permukaan prisma.

Aktivitas 3 bertujuan agar siswa lebih memahami konsep luas permukaan prisma dan menyelesaikan soal/permasalahan dalam kehidupan sehari-hari yang berhubungan dengan luas permukaan prisma. Sebelum melanjutkan pembelajaran guru mengingatkan kembali kepada siswa mengenai pelajaran sebelumnya dengan memberikan beberapa pertanyaan. Selanjutnya guru membagikan LAS 2 yang akan dikerjakan siswa yang terdiri dari 2 kegiatan. Kedua kegiatan ini berisi permasalahan dalam kehidupan sehari-hari yang berhubungan dengan luas permukaan prisma. Siswa berdiskusi pada kelompok, guru menjelaskan hal yang terkait pada LAS tersebut dan guru juga sebagai fasilitator siswa dalam berdiskusi. Untuk soal nomor 1 sampai 3 pada kegiatan 1, siswa mengalami kesulitan dalam mengerjakannnya. Siswa sulit menentukan bangun datar sederhana yang membentuk tenda seperti yang diberikan dalam gambar pada LAS. Berikut transkrip percakapan antara guru ketika membahas kegiatan 1 :

Achmad :"bingung buk jawab nomor 1 ini".

Guru :"kenapa bingung, coba perhatikan baik-baik gambar ini! Mana yang merupakan sisi-sisinya?".
Achmad :"Ini, ini, ini, ini, ini, ini buk" (sambil menunjuk bagian sisi pada gambar tenda)

Guru :"ada berapa bangun yang kamu tunjuk tadi?"

Achmad :"Ada 6 buk"

Guru :"coba sekarang gambarkan semua bangun datar yang kamu tunjuk tadi!"

Achmad :"iya buk"

Guru : :sekarang kamu perhatian lagigambar dan pertanyaannya. Lanjutkan dan diskusikan dengan temannmu"

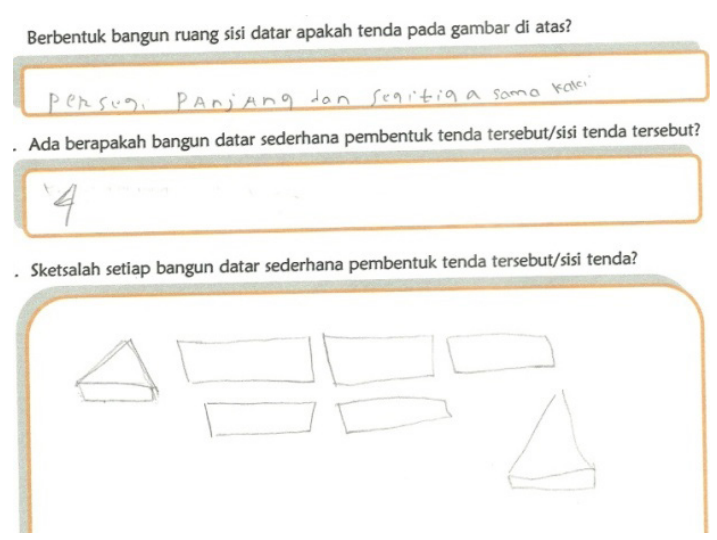

Gambar 5 Contoh jawaban siswa untuk nomor 1 sampai 3 kegiatan 1

Dari gambar 5 dan transkrip 4 terlihat bahwa siswa memberikan jawaban yang kurang tepat. Siswa mengalami kesulitan membayangkan bangun datar yang merupakan sisi tenda. Namun kelompok yang lain sudah bisa menjawab dengan benar soal nomor 1 sampai 3 pada kegiatan 1 meskipun dalam pengerjaannya masih dengan bimbingan guru. Oleh karena itu, untuk siklus 2 gambar tenda pada kegiatan 1 diganti dengan gambar tenda dengan bentuk yang lebih sederhana dibandingkan sebelumnya.

Berikutnya, siswa melanjutkan aktivitas dengan menyelesaikan permasalahan pada kegiatan 2 yaitu berupa permasalahan yang berhubungan dengan kehidupan sehari-hari. Dalam hal ini permasalahan yaitu berupa bangunan bertingkat yang berbentuk prisma segitiga sama sisi. Ketika menyelesaikan permalahan tersebut siswa mengalami kesulitan saat mencari luas bagian atap bangunan. Berikut transkrip percakapan ketika siswa menga- 
lami kesulitan mencari luas segitiga sama sisi dikarenakan belum diketahui tingginya.

\begin{tabular}{|c|c|}
\hline Siswa & $\begin{array}{l}\text { :"buk bagaimana cara mencari luas } \\
\text { bagian atap gedung ini?". }\end{array}$ \\
\hline Guru & :"apa bentuk bagian itu?" \\
\hline Annisa & :"segitiga sama sisi" \\
\hline Guru & $\begin{array}{l}\text { :"berarti pakai luas segitiga dong } \\
\text { mencari luasnya" }\end{array}$ \\
\hline Annisa & $\begin{array}{l}\text { :"iya buk, tapi tinggi segitiganya } \\
\text { belum diketahui. Hanya sisi-sisinya } \\
\text { yang diketahui" }\end{array}$ \\
\hline Guru & $\begin{array}{l}\text { :"kalian sudah belajar phytagoras } \\
\text { belum" }\end{array}$ \\
\hline Annisa & :"sudah buk tapi lupa" \\
\hline Guru & $\begin{array}{l}\text { :"begini caranya" (sambil } \\
\text { menerangkan cara menggunakan } \\
\text { phytagoras) }\end{array}$ \\
\hline & :"ooo, iya buk. Mengerti sekarang" \\
\hline
\end{tabular}

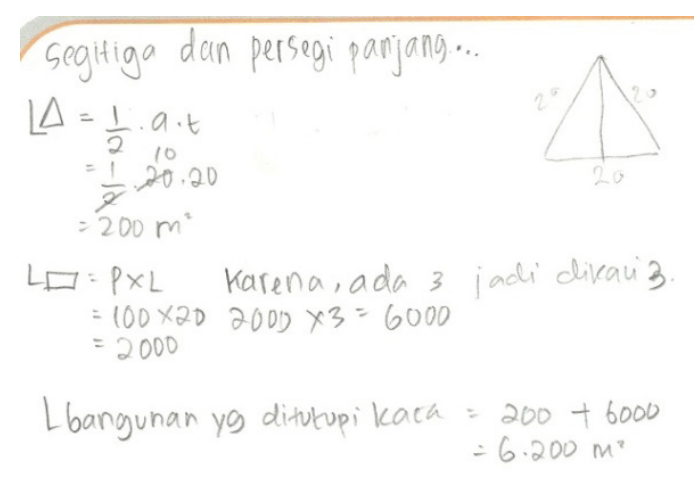

Gambar 6 Contoh jawaban siswa untuk nomor kegiatan 2 LAS 2

Berdasarkan transkrip percakapan 5 dan gambar 6 dapat dilihat bahwa siswa sebetulnya sudah bisa mencari luas bagian atap gedung yang berbentuk segitiga sama sisi. Namun siswa terkendala mencari tinggi segitiga itu. Hal ini dikarenakan siswa lupa dalam menggunakan konsep phytagoras. Setelah guru mengingatkan kembali cara menggunakan phytagoras, siswapun dapat menyelesaikan soal tersebut.

Aktivitas ini bertujuan agar siswa dapat menyelesaikan permasalahan dalam kehidupan sehari-hari yang berhubungan dengan luas permukaan prisma dengan menggunakan konsep mencari luas permukaan prisma yang telah mereka pelajari pada pertemuan sebelumnya. Dari hasil aktivitas pada LAS 2 terlihat bahwa siswa sudah mampu menggunakan pengetahuan mereka dalam mencari luas permukaan prisma. Hanya saja untuk kegiatan 2, siswa masih terkendala dalam menggunakan teorema phytagora. Oleh karena itu, pada siklus 2 guru akan menjelaskan atau memberi apersepsi terlebih dahulu kepada siswa dalam menggunakan teorema phytagoras. Setelah menyelesaikan permasalahan-permasalahan pada LAS 2 siswa mempresentasikan dan membuat kesimpulan. Berdasarkan aktivitas ini, dapat dilihat sejauh mana pemahaman siswa mengenai luas permukaan prisma.

\section{SIMPULAN}

Berdasarkan hasil dan pembahasan yang telah diuraikan, dapat disimpulkan bahwa pendekatan PMRI memiliki peranan penting untuk menghasilkan lintasan belajar siswa dalam pembelajaran prisma untuk membantu siswa menemukan dan memahami konsep luas permukaan prisma di kelas VIII. Melalui aktivitasaktivitas seperti memahami bentuk dan sifat prisma, menemukan dan memahami konsep luas permukaan prisma, dan menyelesaikan permasalahan dalam kehidupan sehari-hari yang berhubungan dengan luas permukaan prisma. Lintasan belajar yang dihasilkan dalam penelitian ini adalah lintasan-lintasan belajar yang dilalui siswa melalui penggunaan kemasan produk dalam memahami luas permukaan prisma dan menyelesaikan permasalahan dalam kehidupan sehari-hari yang berhuungan dengan luas permukaan prisma sebagai aktivitas berbasis pengalaman telah membantu meningkatkan pemahaman siswa tentang luas permukaan prisma. Dalam pembelajaran di dalam kelas, pemahaman siswa terhadap luas permukaan prisma berkembang dari tahap informal menuju tahap formal.

\section{DAFTAR PUSTAKA}

Bonotto, C. (2003). About students' understanding and learning the concept of surface area. In D. H. Clements \& G. Bright (Eds.). Learning and teaching measurement (157-168). Reston: NCTM.

Cavanagh, M. (2008). Area Measurement in Year 7. Educational Studies in Mathematics, 33, 55-58. 
CPRE. (2007). Measurement: Student Misconceptions and Strategies forTeaching. New Jersey: PCK Tools.

French, D. (2004). Teaching and Learning education. New York : Continuum

Gravemeijer, K., \& Cobb, P. (2006). Design Research From A Learning Design Perspective. In J. V. D Akker, K. P. E. Gravemeijer, S. Mckenney, N. Nieven (Eds), Educational Design Research (pp. 17-51). London: Routledge.

Kemendikbud. (2013). Kompetensi Dasar Sekolah Menengah Pertama (SMP) Madrasah Tsanawiyah (MTs). Jakarta: Kemendikbud.

Kershaw, Jen. (2013). Surface Area of triangular Prisma. Kansas: Flexbook.

Nieveen N., McKenny S., dan Akker. (2006). Educational Design Research: The Value of Variety. In d. Akker, Educational Design Research (p. 152). London: Routledge Taylor and Francis Group.

Soedjadi, R. (2007). Inti Dasar-dasar Pendidikan Matematika Realistik Indonesia. Jurnal Pendidikan Matematika, 1(2), 1-10.

Sumardyono. (2012). Geometri Ruang. Yogyakarta:
PPPPTK Matematika.

Wijaya, A. (2012). Pendidikan Matematika Realistic: Suatu Alternative Pendekatan Pembelajaran Matematika. Yogyakarta: Graha Ilmu.

Yan, B, dan Hamdani. (2013). Analisis Kesalahan dalam Menyelesaikan Soal Luas Permukaan serta Volume Bangun Ruang Sisi Datar di SMP. Jurnal UNTAN, 2(9), 1-11.

Yayuk, W. (2010). Pemanfaatan barang bekas sebagai media pembelajaran untuk meningkatkan pemahaman sifat-sifat bangun ruang dalam pembelajaran matematika siswa kelas $\mathrm{V}$ SDN Bocek 02 Kecamatan Karangploso Kabupaten Malang. Penelitian Tindakan kelas. Malang: UM.

Zulkardi \& Putri. (2006). Mendesain Sendiri Soal Kontekstual Matematika, artikel dalam Prosiding in Konferensi Nasional Matematika ke-13 (pp. 1-7). Semarang: Indonesia.

Zulkardi. (2009). The "P" in PMRI: Progress and Problems, artikel dalam ICMA Mathematic Education (pp. 773-780). Yogyakarta: IndoMs. 
